\title{
The unfolded protein response in neurodegenerative diseases: a neuropathological perspective
}

\author{
Wiep Scheper ${ }^{1,2,3} \cdot$ Jeroen J. M. Hoozemans ${ }^{4}$
}

Received: 21 May 2015 / Revised: 14 July 2015 / Accepted: 16 July 2015 / Published online: 26 July 2015

(C) The Author(s) 2015. This article is published with open access at Springerlink.com

\begin{abstract}
The unfolded protein response (UPR) is a stress response of the endoplasmic reticulum (ER) to a disturbance in protein folding. The so-called ER stress sensors PERK, IRE1 and ATF6 play a central role in the initiation and regulation of the UPR. The accumulation of misfolded and aggregated proteins is a common characteristic of neurodegenerative diseases. With the discovery of the basic machinery of the UPR, the idea was born that the UPR or part of its machinery could be involved in neurodegenerative diseases like Alzheimer's disease, Parkinson's disease, amyotrophic lateral sclerosis and prion disease. Over the last decade, the UPR has been addressed in an increasing number of studies on neurodegeneration. The involvement of the UPR has been investigated in human neuropathology across different neurological diseases, as well as in cell and mouse models for neurodegeneration. Studies using different disease models display discrepancies on the role and function of the UPR during neurodegeneration, which can often be attributed to differences in methodology. In this review, we will address the importance of investigation of human brain material for the interpretation of the role of
\end{abstract}

Jeroen J. M. Hoozemans

jjm.hoozemans@vumc.nl

1 Department of Clinical Genetics and Alzheimer Center, Neuroscience Campus Amsterdam, VU University Medical Center, Amsterdam, The Netherlands

2 Department of Functional Genome Analysis and Molecular and Cellular Neuroscience, Center for Neurogenomics and Cognitive Research, VU University, Amsterdam, The Netherlands

3 Department of Genome Analysis, Academic Medical Center, Amsterdam, The Netherlands

4 Department of Pathology, VU University Medical Center, PO Box 7057, 1007 MB Amsterdam, The Netherlands the UPR in neurological diseases. We will discuss evidence for UPR activation in neurodegenerative diseases, and the methodology to study UPR activation and its connection to brain pathology will be addressed. More recently, the UPR is recognized as a target for drug therapy for treatment and prevention of neurodegeneration, by inhibiting the function of specific mediators of the UPR. Several preclinical studies have shown a proof-of-concept for this approach targeting the machinery of UPR, in particular the PERK pathway, in different models for neurodegeneration and have yielded paradoxical results. The promises held by these observations will need further support by clarification of the observed differences between disease models, as well as increased insight obtained from human neuropathology.

Keywords ER stress - Unfolded protein response · PERK $\cdot$ eIF2alpha $\cdot$ Neuropathology $\cdot$ Neurodegeneration

\section{The UPR, a highly conserved stress response}

Neurodegenerative disorders like Alzheimer's disease (AD), Parkinson's disease (PD), prion disease, Huntington's disease (HD), frontotemporal dementia (FTD), and amyotrophic lateral sclerosis (ALS) are characterized by the accumulation and aggregation of misfolded proteins. The proteins found in the aggregates and the brain areas where they accumulate are different for each neurodegenerative disease. Like all cells, neurons have an extensive system for protein quality control. This serves to detect and remove aberrant proteins, to prevent the detrimental aggregation process and deal with misfolding early in the process. A major site of protein synthesis is the endoplasmic reticulum (ER), where secretory, transmembrane and organelle-targeted proteins are synthesized, comprising 
approximately $30 \%$ of the proteome. A key component of protein quality control in the ER is the unfolded protein response (UPR), which comes into play if the protein homeostasis (proteostasis) in the ER is disturbed.

Before the UPR was discovered, it had already been observed that different types of cellular stress like viral transformation, inhibition of glycosylation and calcium ionophore treatment induced the expression of a select group of proteins. These proteins were called glucoseregulated proteins (GRPs) because of their induction by glucose deprivation and to distinguish them from a related group of proteins that were induced by heat, the heatshock proteins [53, 104]. In 1988, the first direct connection between protein folding stress in the ER and the induction of GRPs, including GRP78 (BiP), was made by overexpression of mutant influenza hemagglutinin protein in mammalian cells [52]. This stress response was thus designated unfolded protein response or UPR. Gradually, the key signaling events that mediate the response were identified, with pioneering work done in yeast, demonstrating that a specific promoter element is responsible for the transcriptional upregulation of GRPs and other targets [67]. This was followed by the identification of the sensor in the ER membrane responsible for transducing the signal from the misfolded proteins in the ER to the nucleus (Ire1p/Ern1p), reported more or less simultaneously by two groups $[18,66]$. Two mammalian homologues (IRE1 $\alpha$ and $\beta$ ) were identified a few years later [109, 119]. Ire1p oligomerizes when the response is triggered which results in trans-autophosphorylation [94, 120]. An important result of activation of Ire1p is the unconventional splicing of Hac1p mRNA, resulting in the generation of the active transcription factor Hac1p [19, 98]. The mammalian substrate of the IRE1 endonuclease, XBP1 mRNA, has remained elusive for a long time as it bears no homology to Hac1p. Nonetheless, the mechanism of activation by unconventional splicing is conserved [11, 55, 126].

The yeast UPR is mediated entirely by the Ire $1 p$ pathway, but metazoans have additional sensors and, as a result, more downstream targets and broader cellular effects. It was observed that during activation of the UPR in mammalian cells protein synthesis is inhibited by phosphorylation of the translation initiation factor eIF $2 \alpha$, as is also a common response to other types of cellular stress [later termed the integrated stress response (ISR), see below]. However, none of the eIF $2 \alpha$ kinases known at the time were activated by ER stress. Protein kinase R (PKR)-like endoplasmic reticulum kinase (PERK), an ER transmembrane protein, was later identified as this novel eIF2 $\alpha$ kinase $[33,95]$. It combines the interesting properties of a luminal domain highly homologous to IRE1 to sense misfolded proteins in the ER connected to a cytosolic kinase domain that resembles the other eIF2 $\alpha$ kinases. Mammalian cells contain

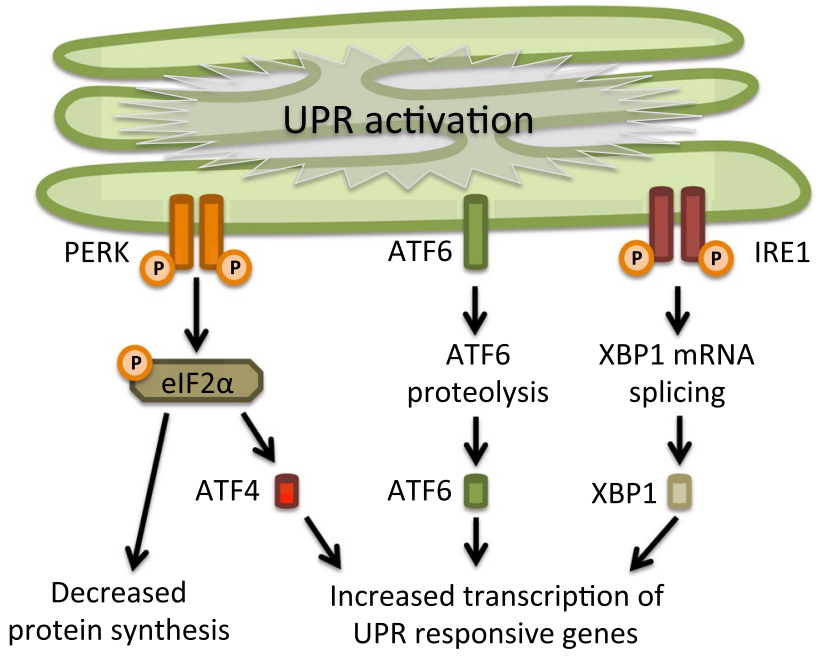

Fig. 1 The unfolded protein response. The unfolded protein response consists of three independent signaling pathways that work in parallel and are activated upon accumulation of unfolded proteins inside the ER. Each signaling pathway is defined by the different ER-resident transmembrane proteins that act as ER stress sensors: RNA-activated protein kinase R (PKR)-like ER kinase (PERK), activating transcription factor 6 (ATF6) and inositol requiring enzyme 1 (IRE1). Activation of the UPR leads to an overall translational block and specific activation of ER stress responsive genes, which will increase the protein folding capacity and decrease the protein folding load in the ER. See text for further details

another ER stress transducer, the third in line to be discovered, activating transcription factor 6 (ATF6). This membrane-bound transcription factor is transported to the Golgi upon UPR activation where it is processed and released to the nucleus [34, 125]. As for IRE1, for ATF6 also two isoforms exist, ATF6 $\alpha$ and ATF6 $\beta$.

The IRE1, PERK and ATF6 pathways together comprise an intricate network that has a broad range of transcriptional and translational targets. The UPR is closely connected to the proteolytic machinery of the cell. Proteins that misfold in the ER are exported to the cytosol and degraded by the proteasome [80]. However, once the UPR is activated, autophagy is increased and this becomes the major proteolytic system [5, 24, 69, 73, 90]. Although many mechanistic details and additional regulatory pathways are still being uncovered, the core signaling of the mammalian UPR had been unraveled by 2002 (Fig. 1).

An important function of the UPR is its function as a homeostatic stress response initiated by ER dysfunction. In addition, it is employed to adjust the physiology of cells under situations where ER function is not impaired [81]. For example, during the differentiation of B-cells to antibody-producing plasma cells, pathways of the UPR are employed to expand the ER [46]. Also in cells that demonstrate a highly dynamic physiologically regulated range of secretory demand, like insulin secretion in pancreatic 
$\beta$-cells, the UPR is involved [91]. Not surprisingly, dysfunction of the UPR can therefore give rise to disease. For example, Wolcott-Rallison syndrome is a rare hereditary disease caused by loss of function of PERK [23]. Individuals with this disease develop defects that are connected to loss of the physiological function of the UPR, including diabetes due to loss of $\beta$-cell function. A completely opposite way in which the UPR can lead to disease is observed in cancer, where hyperactivity of the UPR facilitates the survival of tumor cells [63]. In contrast, in neurodegenerative diseases - the focus of this review-UPR activation is connected to ER dysfunction and leads to loss of neuronal function. It is important to be aware of the different faces that the UPR has in physiology and pathology.

Because accumulation of misfolded proteins is a common characteristic of neurodegenerative diseases, it is not surprising that the involvement of the UPR during neurodegeneration has been extensively studied in both in vitro and in vivo models (for review see [79]). It is becoming apparent that the role of the UPR in these models is not always consistent and sometimes even paradoxical (see detailed discussion below). The proposed functional role of the UPR concluded from these models is often difficult to connect to the situation in the human brain under pathological conditions. To understand the impact or relevance of the UPR in vitro or in vivo using models for neurodegeneration a direct relation should be made with human neuropathology. In 2005, our group reported activation of the UPR in human AD brain [42]. The investigation of many different neurodegenerative diseases in even more different model systems has increased enormously. Below, we will discuss the progress made in UPR research in neurodegenerative diseases over the last decade. We will specifically address similarities and discrepancies between observations in human pathology and disease models.

\section{UPR activation in human neuropathology}

To detect UPR activation in samples of human brain, different methods can be employed. Altered expression of UPR target genes can be determined by analysis of mRNA expression in brain lysates. This is a sensitive method, but has the disadvantage that changes in only a subset of the cells may not be detected because they are diluted out. The same limitation applies to measuring protein levels of UPR markers in protein lysates. Currently, many antibodies are available directed to the main players of the UPR that enable studying its activation using different techniques. It should be noted that determination of UPR protein levels not always allows assessment of UPR activation since part of the UPR relies on mechanisms that involve protein cleavage, post-translational modification, intracellular distribution or altered conformation.

For detection of UPR activation, phospho-specific antibodies that specifically detect the active, phosphorylated, forms of the ER stress sensors PERK and IRE1 have become an important tool. Also, for the phosphorylated substrate of PERK, p-eIF $2 \alpha$, phospho-specific antibodies are available, but this is not a specific UPR marker, because it is the converging point of the ISR. The ISR involves apart from PERK three other stress-induced eIF2 $\alpha$ kinases, PKR (protein kinase double-stranded RNA-dependent), GCN2 (general control non-depressible-2), and HRI (heme-regulated inhibitor) [25]. In addition, immunohistochemistry or immunofluorescence can be employed for UPR-related translocation events, of the transcription factors ATF6 and XBP1 to the nucleus. In addition, ATF4 and CHOP positive nuclei are in accordance with UPR activation, but again these downstream targets in the PERK pathway are not specific UPR markers because of the presence other eIF $2 \alpha$ kinases. An additional advantage of UPR detection in situ by immunohistochemistry or immunofluorescence is that it can be pinpointed to specific cells (e.g., neurons or glia) and directly correlated to pathological hallmarks. Using above-described methods, different UPR markers have been observed in different neuropathological conditions (Table 1).

\section{Alzheimer's disease}

Alzheimer's disease (AD) is the most prevalent neurodegenerative disease and the most common form of dementia. Deposits of aggregated proteins are a prominent neuropathological hallmark of AD: intracellular aggregates of tau in the neurofibrillary tangles (NFTs), dystrophic neurites and neuropil threads, and extracellular aggregates of $\beta$-amyloid $(\mathrm{A} \beta)$ in the senile plaques. AD thus represents a prime example of a protein folding disease [106]. Markers specific for UPR activation are increased in AD brain tissue compared to non-demented control brain tissue (Fig. 2). GRP78 is increased in AD in the hippocampus and temporal cortex and various studies from different groups have shown increased presence of phosphorylated (p)PERK, pIRE1, and p-eIF2 $\alpha$ in AD neurons [15, 29, 41, $42,103,111]$. These markers appear either in morphologically healthy neurons or in neurons with abnormally phosphorylated tau protein, but are almost absent from NFTcontaining neurons. Overall, the levels of GRP78 and the occurrence of pPERK in AD neurons correlate very well with the presence of abnormally phosphorylated tau and the Braak staging for NFTs [41]. These observations indicate that the UPR is involved in the early stages of $A D$ pathology. 


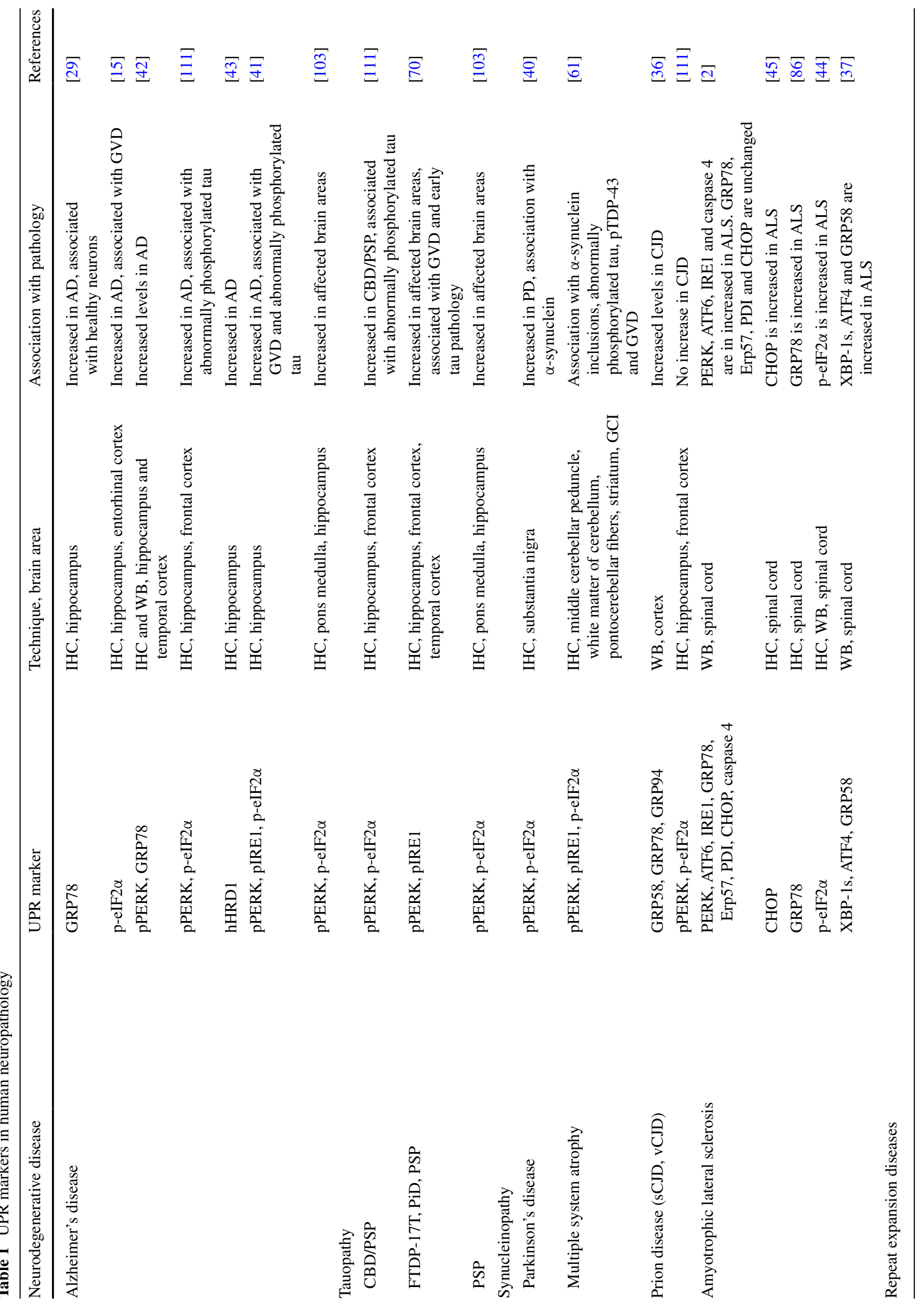




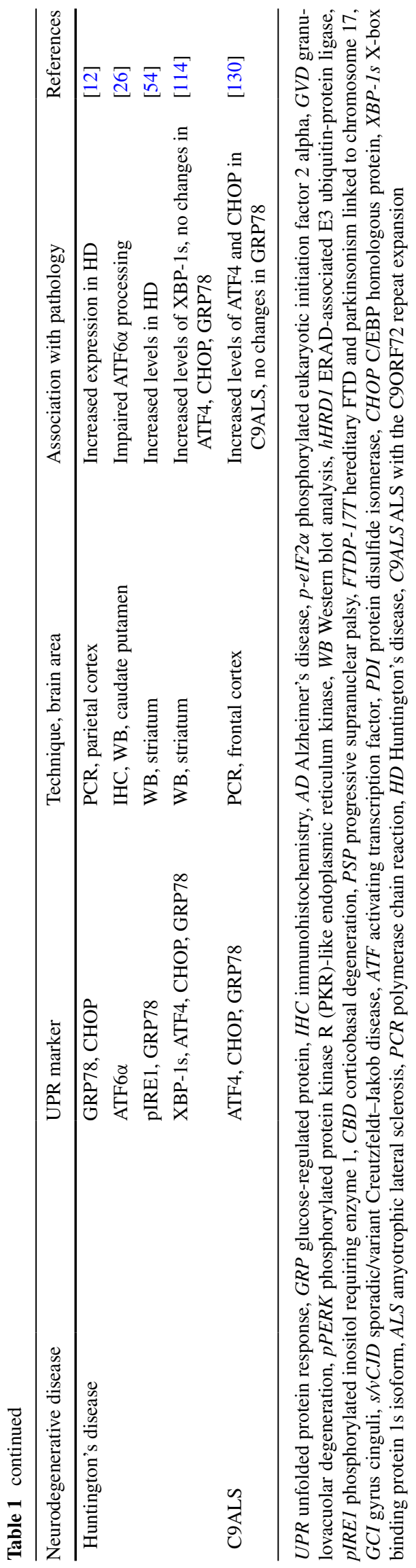

\section{Non-AD tauopathies}

Neurodegenerative diseases that show a primary pathology consisting of inclusions of filamentous tau can be designated as a tauopathy and include diseases like sporadic corticobasal degeneration (CBD), progressive supranuclear palsy (PSP), Pick's disease (PiD), as well as hereditary FTD and parkinsonism linked to chromosome 17 (FTDP17T). Different groups have now shown increased presence of pPERK, p-eIF2 $\alpha$ and pIRE1 in affected brain areas in these tauopathies [70, 103, 111]. From these studies, it appears that UPR activation markers occur in cells, i.e., neurons and glia that show abnormal tau phosphorylation, suggesting that UPR activation and tau phosphorylation are closely linked during neurodegeneration.

\section{Synucleinopathies}

Parkinson's disease (PD) is characterized by the selective loss of dopaminergic neurons in the substantia nigra pars compacta $(\mathrm{SN})$ and the accumulation of $\alpha$-synuclein in Lewy bodies. The involvement of the UPR in PD has primarily been shown in in vitro models [82]. Although a role for the UPR in neuronal cell death in PD pathogenesis is widely suggested, there is hardly any data on UPR activation from postmortem studies on PD cases. Our group investigated the immunohistochemical localization of pPERK and p-eIF2 $\alpha$ in the substantia nigra of PD and control cases [40]. Immunoreactivity for pPERK and p-eIF $2 \alpha$ is observed in PD in neuromelanin containing neurons of the SN, while these markers are absent in control cases. Multiple system atrophy (MSA) is a sporadic neurodegenerative disease that is also characterized by intracellular accumulation of $\alpha$-synuclein. In MSA, pPERK, p-eIF2 $\alpha$, and pIRE1 were increased in and closely associated with glial cytoplasmic inclusions containing $\alpha$-synuclein during the initial state of deposition [61]. The close association between UPR markers and accumulation of $\alpha$-synuclein in the cytoplasm suggests a strong relation between $\alpha$-synuclein and ER stress. This is supported by in vitro models showing that overexpression of wild-type or mutant $\alpha$-synuclein increases the vulnerability for ER stress through various mechanisms $[17,100]$.

\section{Prion disease}

Prion disease or transmissible spongiform encephalopathies (TSEs) are fatal neurodegenerative disorders (e.g., Creutzfeldt-Jakob (CJD), Gerstmann-Sträussler-Schenker disease (GSS), fatal familial insomnia (FFI), and Kuru), which are characterized by rapidly progressing neuronal loss and extracellular accumulation of the scrapie form of the prion protein $\left(\mathrm{PrP}^{\mathrm{Sc}}\right)$, a pathological isoform of the 

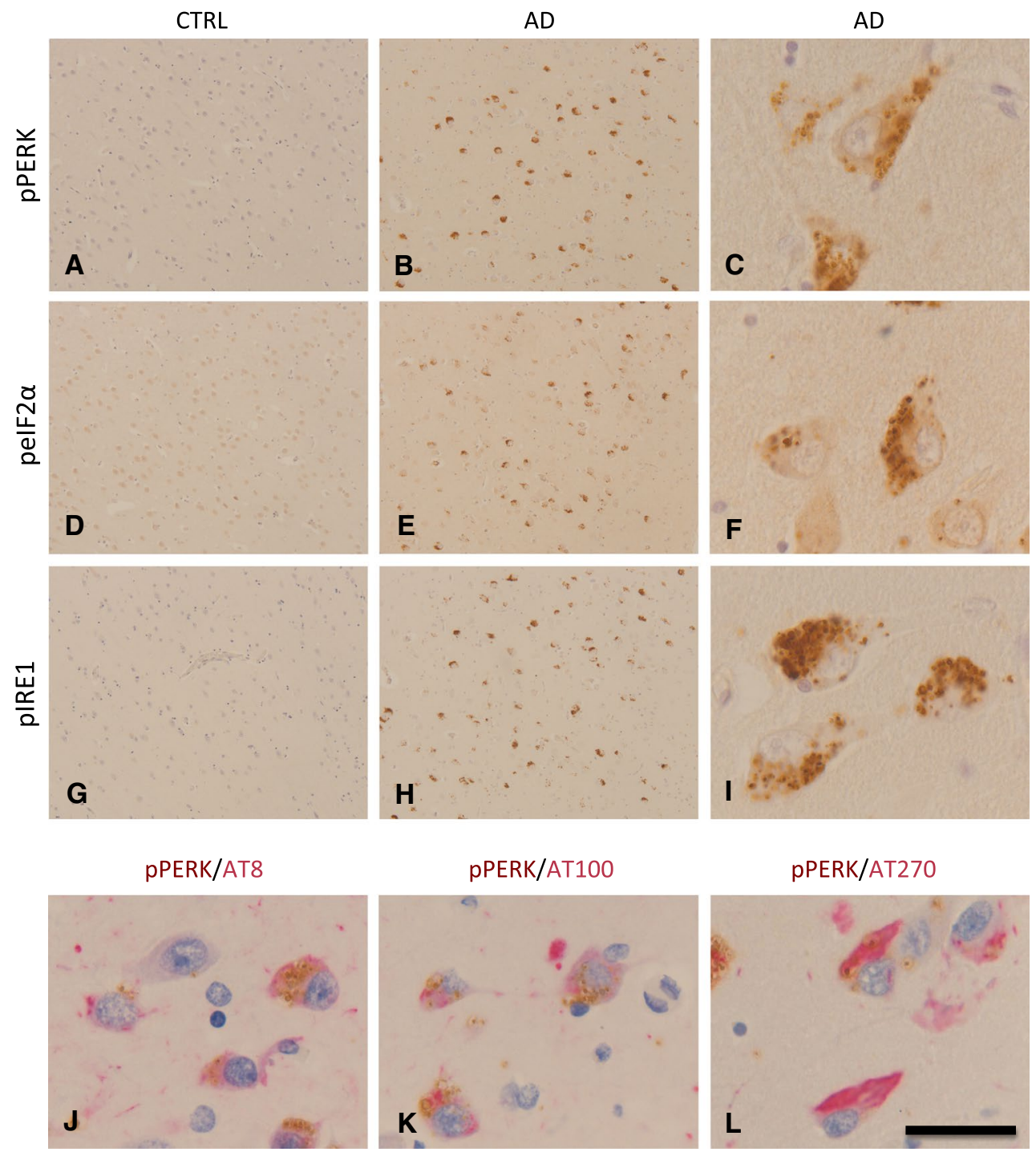

Fig. 2 UPR activation in Alzheimer's disease. Immunohistochemical detection and antibodies used for the detection of UPR markers and phosphorylated tau (AT8, AT100 and AT270) have been described previously [41, 42]. Shown are pictures of the hippocampal sub-area subiculum of a control case (CTRL, Braak 0) and an AD case (Braak 5). a-c pPERK is detected by immunohistochemistry in pyramidal neurons of an AD case and is absent in a control case showing no $\mathrm{AD}$ pathology. pPERK is present in granules which can be defined as granulovacuolar degeneration. d-f p-eIF $2 \alpha$ immunohistochemistry on the same area shown for the control and AD case in a-c. Also p-eIF $2 \alpha$ can be detected as granules in pyramidal neurons. $\mathbf{g}-\mathbf{i}$

normal cellular prion protein (PrP). Detection of UPR activation markers, especially phosphorylated proteins, could be difficult in human prion disease due to the relatively long postmortem delay as a result of infectivity precautions. In 2003, Hetz and colleagues reported on increased caspase-12 activation and elevated levels of ER stress markers GRP58, GRP78 and GRP94 in cortical samples from sporadic CJD and variant CJD cases [36]. The role of
pIRE1 $\alpha$ is also detected in pyramidal neurons in the subiculum of an AD case and is absent in a control case (shown is the same area as indicated in $\mathbf{a}-\mathbf{c}$ ). Similar granular structures are detected as observed with pPERK and p-eIF2 $\alpha$ immunohistochemistry. $\mathbf{j}-\mathbf{k}$ UPR markers in $\mathrm{AD}$ are localized in neurons showing increased presence of phosphorylated Tau protein; j Double immunolabeling for pPERK (brown) and AT8 (red, pTau Ser202), k pPERK (brown) and AT100 (red, pTau Ser212 and Thr 214) and I pPERK (brown) and AT270 (red, pTau Thr181). Sections were counterstained with haematoxylin (blue). Scale bar $\mathbf{a}, \mathbf{b}, \mathbf{d}, \mathbf{e}, \mathbf{g}, \mathbf{h} 300 \mu \mathrm{m} ; \mathbf{c}, \mathbf{f}, \mathrm{i}-\mathbf{l} 40 \mu \mathrm{m}$

caspase-12 in neurodegeneration in general and in human neuropathology in particular is debatable. In mice, caspase- 12 is also involved in the innate immune responses by regulating the processing of inflammatory cytokines and caspase-12 deficiency in mice confers resistance to sepsis [83]. In the great majority of the human population, however, caspase-12 is expressed as a truncated, catalytically inactive protein. A subset of individuals of African descent 
expresses full-length caspase-12 rendering these individuals more susceptible to inflammatory diseases, again pointing more to a key role for this caspase in the immune response [84]. These issues should be kept in mind considering the interpretation of caspase-12 activation in human brain tissue samples.

An extensive immunohistochemical study looking at the localization of pPERK and p-eIF $2 \alpha$ could not confirm the involvement of the UPR in CJD [111]. Only CJD cases that showed concomitant AD pathology had increased presence of pPERK and p-eIF2 $\alpha$, suggesting that these markers were not related to the prion pathology. This indicates that comorbidity or co-occurrence of neuropathological processes is an important factor in the study of UPR activation in human neuropathology. Definite conclusions can only be made when brain tissue is neuropathologically assessed for different pathological hallmarks, particularly abnormally phosphorylated tau. Whether other arms of the UPR than the PERK pathway are involved in human CJD pathology needs to be addressed in future studies.

\section{Amyotrophic lateral sclerosis}

Amyotrophic lateral sclerosis is characterized by the degeneration of motor neurons in the spinal cord, cortex and brain stem, leading to muscle atrophy and paralysis [10]. Protein levels of total PERK, ATF6, IRE1 and caspase- 4 are increased in the spinal cord of sporadic ALS patients [2]. In addition, increased levels of XBP-1s, ATF4 and GRP58 have been observed in human postmortem spinal cord samples of sporadic ALS patients by Western blot analysis [37]. Immunohistochemical analyses indicate an increase in CHOP and GRP78 in ALS spinal cord [45, 86]. pPERK and p-eIF $2 \alpha$ have been observed in the spinal cord of transgenic mice models for ALS [68]. To our knowledge, there are no reports on increased levels of pPERK in ALS spinal cord. By both immunohistochemistry and Western blot analyses, increased levels of p-eIF $2 \alpha$ are detected in spinal cord samples from patients with sporadic ALS compared control cases [44]. UPR activation has been thoroughly investigated in models for ALS and increased levels of a variety of UPR markers have been reported in spinal cord samples from ALS patients. However, it should be noted that comparative studies on human postmortem spinal cord samples from ALS patients and matched control cases to date only comprised low number of cases making statistical analysis difficult.

\section{Repeat expansion diseases}

Expanded polyglutamine (polyQ) repeats found in different proteins can cause human-inherited neurodegenerative diseases, such as Huntington's disease (HD), spinobulbar muscular atrophy, dentatorubal-pallidoluysian atrophy and spinocerebellar ataxia (SCA). These disorders are characterized by accumulation of intracellular protein aggregates and selective neuronal death. Expression levels of GRP78 and CHOP mRNA were found to be increased in the parietal cortex of HD patients compared to control cases [12]. Increased protein levels of pIRE1 and GRP78 can be observed in striatal tissue of HD patients compared with controls by Western blot analysis [54]. Vidal and colleagues have reported increased protein expression of XBP-1s in the striatum of a subset of HD cases compared with control cases, while no detectable changes in protein levels were observed for ATF4, CHOP, and GRP78 [114]. Another study showed that the processing of ATF6 to its active nuclear form is impaired in affected brain regions of Huntington's disease patients [26].

$\mathrm{A}_{4} \mathrm{C}_{2} \cdot \mathrm{G}_{2} \mathrm{C}_{4}$ repeat expansion in a non-coding region of the C9ORF72 gene is the most common genetic cause of ALS and FTLD-TDP [22, 78]. In the frontal cortex, mRNA levels of ATF4 and CHOP are significantly increased in ALS patients with the C9ORF72 repeat expansion compared to ALS patients without the repeat expansion, whereas no differences in GRP78 mRNA levels were observed [130].

From observations in postmortem brain, it is hard to draw conclusions about the involvement of the UPR in repeat expansion diseases. Most studies have been performed with a low number of disease and control cases and do not show the association with the extent of pathology or the number of repeat expansions in the affected genes. This makes statistical analysis and interpretation of data very difficult. More extensive studies on UPR markers are required to determine the role of the UPR in repeat expansion diseases.

\section{UPR markers are associated with granulovacuolar degeneration}

In various neurodegenerative diseases (AD, tauopathies, MSA), UPR activation markers are observed in neuropathological structures that are defined as granulovacuolar degeneration (GVD). GVD is characterized by basophilic granules surrounded by a clear zone measuring $1-5 \mu \mathrm{m}$ in diameter, occurring predominantly in hippocampal neurons [74, 107]. It is reported that GVD occurs in adult control brains and increases slightly with increasing age, however, the occurrence of GVD in AD brain is increased compared to age-matched control brain [4, 122]. In addition, the occurrence of GVD is associated with pathological hallmarks and clinical signs of $\mathrm{AD}$ as it correlates with the presence of NFTs, neuritic plaque pathology, $A \beta$-protein deposition phases, cerebral amyloid angiopathy stages and clinical dementia rating (CDR) scores [107]. Currently, the 
molecular events in GVD-containing neurons are poorly understood. Histochemical and ultrastructural observations suggest that GVD may correspond to a special type of autophagosome [74]. The presence of UPR activation markers in GVD granules may be explained by inclusion of ER-derived material in the autophagosomes. Alternatively, there is evidence indicating that the ER can serve as a membrane source for autophagosome formation [6].

\section{Conclusions from neuropathogical studies}

All neurodegenerative diseases described above show features of an activated UPR. The most elaborate insight with regard to the association with pathological hallmarks and disease progression has been obtained for AD. Insight in the involvement of the UPR in different pathological stages (e.g., Braak stage for NFT of LB, Thal staging for amyloid $\beta[8,9,108])$ will provide directions for functional studies into the involvement of the UPR in neurodegenerative models, and feasibility of potential therapeutic approaches. For most neurodegenerative diseases studied, the assessment of the three arms of the UPR together is lacking, although this is important in view of crosstalk and compensation between the pathways (see detailed discussion below). Several factors can directly or indirectly influence the activity of the three ER stress transducers which may fine-tune the output of the UPR in physiological conditions. This has been best studied for the IRE1 pathway (reviewed in [35]). IRE1 has been implicated in determining the switch from adaptive to apoptotic signaling if the stress is prolonged, which is then followed by apoptosis [30]. However, prolonged activity of all 3 branches is observed in several neurodegenerative diseases in the absence of signs of apoptosis. This indicates that the dysregulated UPR activity in pathological situations is very different from that observed in physiological cell models. A noteworthy observation across the different neurodegenerative diseases is the association of UPR activation markers with the occurrence of early signs of tau pathology. In AD, CBD, PSP, PiD, FTDP-17T and MSA, UPR activation is found in neurons that show accumulation of abnormally phosphorylated tau. These observations across different diseases strengthen the hypothesis that UPR activation and abnormal tau phosphorylation/aggregation are functionally connected.

\section{UPR activity in models for neurodegenerative disease: truth or artifact?}

To model neurodegenerative diseases, overexpression of aggregating proteins and more often of mutant derivatives associated with familial variants of the disease is used. Typically, this models only part of the pathogenesis in an exaggerated and accelerated fashion. This is useful for some purposes, but also creates an artifact-prone situation, in particular for a response that is designed to detect protein stress. A good example of ambiguous results is Presenilin 1 (PS1), mutations in which are the most common cause of autosomal dominant inherited forms of AD. PS1 was reported to affect the signaling of the UPR in models using overexpression [48] as well as knockout [71]. In contrast, other labs did not observe effects of PS1 mutant overexpression or deficiency on the UPR $[75,87,101]$. The exact cause of these differences is not known, and may relate to different cells, promoters and expression levels, mouse lines, specific mutations in PS1 used, etc. In any case, it is clear that disturbed UPR signaling is not a common feature of PS1 mutations and, in addition, it is elusive whether UPR signaling is activated and involved in the pathogenesis of AD in PS1 mutation carriers.

Several groups reported that exogenous application of synthetic $A \beta$ induces or potentiates the UPR, albeit to different extent [14, 105, 127]. What is important to realize is that the local amounts of aggregates in these experimental setups exceeds that observed in the brain excessively. In an animal model for prion disease, injection of $\operatorname{PrP}^{\mathrm{sc}}$ in the brain of mice results in UPR activation [65]. Although the exposure to $\operatorname{PrP}^{\mathrm{sc}}$ reflects the pathogenesis of the human sporadic disease relatively well, in most experiments it still involves exposure to higher levels of aberrant proteins in $\mathrm{Tg}$ mice that express higher levels of the normal $\operatorname{PrP}^{\mathrm{c}}$ to speed up the pathology. The flooding of neurons and synapses with toxic aggregates may lead to a disturbance in the ER, however, this may relate to a more general disturbance of cell physiology rather than a specific effect on the UPR. It was reported that UPR activation is also observed in the absence of overexpressed $\operatorname{PrP}^{\mathrm{c}}$ [65] and although this will increase the time for phenotypes to develop this may be a more artifact-free model for the human disease.

This indicates another important issue: The aggregating proteins in neurodegenerative disease do typically not accumulate in the ER and many of them do not enter the ER at any stage in their life cycle. Effects on UPR signaling may therefore be indirect or not even directly related to ER stress. For example in the prion disease model, PERK activation does not seem to be accompanied by activation of the other two UPR branches, which makes it a very specific type of PERK activation, possibly not via ER stress $[65,72]$. In overexpression models for $\alpha$-synuclein [17], it was shown that accumulation of $\alpha$-synuclein in the cytosol blocks ER-Golgi trafficking, leading to reduced ER exit and induction to the UPR. In another example, our own lab found that incubation of neuronal cells in culture with neurotoxic concentrations of $\mathrm{A} \beta$ oligomers did not induce a robust UPR within $48 \mathrm{~h}$ [14], although the uptake of oligomers occurs within minutes after application [13]. The 
oligomers did not directly encounter the ER, but did sensitize cells for a secondary ER stress insult. It is for example possible that the oligomers disturb intracellular calcium homeostasis via their toxic effect on mitochondria and lysosomes, thus indirectly affecting calcium homeostasis in the ER.

The lack of a direct colocalization between the disease causing proteins and the ER has prompted research into investigating the connection the other way around and consider the option that UPR activation precedes and facilitates pathology. There is for example no evidence for UPR activation by $\mathrm{A} \beta$ pathology in APP/PS1 mice. These only show UPR activation in aged mice, despite extensive pathology much earlier in younger mice [50].

Recent studies show that in animal models for prion disease and $A \beta$ pathology increased PERK activity results in chronic inhibition of protein synthesis by eIF $2 \alpha$ phosphorylation $[60,64,65]$. This prolonged UPR activation results in reduced levels of synaptic proteins and induces synaptic loss and neurodegeneration. This is an exciting new view on how chronic activation of the UPR facilitates neurodegeneration [89]. Although overall translation is inhibited by eIF $2 \alpha$ phosphorylation, the translation of a select set of mRNAs is increased under these conditions. The mRNA encoding BACE1, a key enzyme in $\mathrm{A} \beta$ formation, was demonstrated to be one of these transcripts. BACE1 is thus subject to PERK-mediated translational upregulation via eIF2 $\alpha$ phosphorylation. This UPR-induced increase in BACE1 levels results in enhanced $\mathrm{A} \beta$ production in $\mathrm{Tg} 2576$ mice [72]. This corroborates with an earlier report showing that UPR activation increases the formation of $A \beta$ in PS1 mutant fibroblasts [75] although in this study the involvement of the PERK pathway was not specifically addressed.

As was observed in the APP/PS1 mice also in transgenic tau mice (P301L), the UPR is activated only in aged mice $[38,50]$. UPR activity occurs therefore well after the occurrence of tau pathology, which makes it unlikely that pathological tau induces the UPR. In contrast, both in cell culture [113] and animals [56] endogenous tau is phosphorylated at disease relevant epitopes upon induction of the UPR. This suggests that activation of the UPR facilitates tau pathology. Results from our lab indicate that initially the UPR-induced tau phosphorylation is reversible and may be part of the adaptive response to stress [113]. However, prolonged UPR activation and tau phosphorylation as occurs in the brains of tauopathy patients may facilitate the formation of irreversible tau aggregates. In a very aggressively progressing tau mouse model ( $\mathrm{Tg} 4510)$ that shows extremely rapid tau aggregation and neuronal loss, it was shown that the tau aggregates impair ER proteostasis, thus contributing to activation of the UPR [1]. This may in turn result in a vicious cycle once aggregates form and may explain the UPR induction in aged tau mice [102]. The
UPR-induced tau phosphorylation can be inhibited using a small molecule inhibitor of the PERK pathway [113], suggesting the involvement of this pathway.

Interestingly, subtle changes in UPR activity could bear relevance in human disease. Recently, this has gained further support from genetic studies that associate the $E I F 2 A K 3$ gene with increased risk of the tauopathies PSP and $\mathrm{AD}[39,58]$. The EIF $2 A K 3$ risk allele was shown to increase the signaling activity of the PERK pathway [57]. Likewise, a polymorphism in the XBPI gene, which encodes the transcription factor activated by the IRE1 branch of the UPR, was identified as a genetic risk factor for AD [59]. The polymorphism affects the expression of XBP-1 and thereby the signaling activity in the IRE1 pathway $[47,77]$.

Despite the use of different animal and cell models for some specific mechanistic questions, many of these are quite different from the human disease. Recent advances in induced pluripotent stem cell (iPSC) technology lead the way to the generation of disease relevant human neurons. Cortical neurons derived from sporadic AD and APPE693 $\triangle$ fAD fibroblasts showed extensive intracellular $A \beta$ oligomer accumulation and increased GRP78 mRNA levels in particular in the fAD mutant cells, but involvement of other components of the UPR was not reported [51]. Human motor neurons derived from SOD1 A4V fALS mutation carrier fibroblasts causes hyperexcitation associated with upregulation of XBP-1s and increased p-eIF2 $\alpha$ [115]. Inhibition of the hyperexcitation reduces the levels of XBP-1s, indicating that it is downstream of the electrophysiological phenotype [115]. It was suggested that this could induce a vicious cycle, because UPR induction has been shown to increase activity in motor neurons [49]. The exact mechanism needs further investigation, because if the signaling via the PERK pathway was prolonged using Salubrinal treatment the neuronal activity was actually reduced. Interestingly, these events all preceded the aggregation of the mutant SOD protein [49]. The data suggested that the levels of UPR target proteins are relatively high in wild-type motor neurons, indicative of basal UPR activation. Because this is associated with a relatively high sensitivity to ER stress, this could be an interesting explanation for the selective motor neuron pathology in ALS. The developments in the technology to culture human neurons create an elegant model to further elaborate on this, also in less-severe disease variants than the $\mathrm{A} 4 \mathrm{~V}$ mutant [92]. Cortical neurons were derived from A53T $\alpha$-synuclein fibroblasts to establish a model for cortical synucleinopathy [16]. As was shown in yeast and mammalian cell models before, these cells display accumulation of ERAD substrates in the ER and increased levels of the UPR targets GRP78 and PDI. Also, in this case, the added value of human neurons was indicated, as all these phenotypic changes required neuronal differentiation. 
Table 2 Small molecules targeting the PERK pathway of the UPR: effects in mouse models for neurodegenerative disease

\begin{tabular}{|c|c|c|c|c|c|}
\hline Compound & Target & p-eIF $2 \alpha$ & Disease model & Disease effect & References \\
\hline Salubrinal & PPP1R15A(GADD34)-PP1c/PPP1R15B-PP1c & $\uparrow$ & $\begin{array}{l}\text { ALS (SOD1G93A) } \\
\text { Prion disease }\end{array}$ & $\begin{array}{l}\text { Beneficial } \\
\text { detrimental }\end{array}$ & $\begin{array}{l}{[7,88]} \\
{[65]}\end{array}$ \\
\hline Guanabenz & PPP1R15A(GADD34)-PP1c & $\uparrow$ & $\begin{array}{l}\text { ALS (TDP-43) } \\
\text { ALS (SOD1 G93A) }\end{array}$ & Beneficial & {$[110,112,118]$} \\
\hline Sephin 1 & PPP1R15A(GADD34)-PP1c & $\uparrow$ & ALS (SOD1G93A); CMT1B & Beneficial & {$[21]$} \\
\hline GSK2606414 & PERK inhibitor & $\downarrow$ & Prion disease & Beneficial & {$[3,64]$} \\
\hline ISRIB & eIF2 $\beta$ & Not changed & Prion disease & Beneficial & {$[28,93,96]$} \\
\hline
\end{tabular}

$P E R K$ protein kinase $\mathrm{R}$ (PKR)-like endoplasmic reticulum kinase, UPR unfolded protein response, $p$-eIF2 $\alpha$ phosphorylated eukaryotic initiation factor 2 alpha, eIF2 $\beta$ eukaryotic initiation factor 2 beta, GADD34 growth arrest and DNA damage-inducible protein 34, PP1c protein phosphatase 1c, $P P P 1 R 15 A / B$ protein phosphatase 1, regulatory subunit $15 \mathrm{~A} / \mathrm{B}, A L S$ amyotrophic lateral sclerosis, $C M T 1 B$ Charcot-Marie-Tooth disease 1B, TDP-43 TAR DNA-binding protein 43, SOD1 superoxide dismutase 1

\section{Targeting the UPR}

Many models for neurodegenerative disease show UPR activity, but how do changes in UPR signaling affect the neurodegenerative process? This is important from mechanistic point of view, but also when considering targeting of the UPR for treatment of neurodegenerative disease.

Knockout mice for the UPR sensors were generated already early after their discovery and very severely affect the development and physiology of the animals. Homozygous PERK $-/-$ mice have a phenotype very similar to humans with Wolcott-Rallison syndrome, in which the gene encoding PERK (EIF2AK3) is mutated [23]. Very pronounced is the defect in the function of the endocrine and exocrine pancreas, resulting in many systemic problems and early mortality [31, 129]. PERK-deficient cells are more sensitive for ER stress [32]. ATF6 $\alpha$ deficiency also increases sensitivity for ER stress and ATF6 $\alpha \beta$ double knockouts are embryonic lethal [121, 123, 124]. Also, germline deletion of XBPI [76] or IREI $\alpha$ [128] in mice is embryonic lethal.

The apparently increased sensitivity for ER stress in carriers of the UPR risk alleles may result in pathology in the long run. More research will be needed to establish how these risk variants contribute to pathology. The existence of risk variants may imply that also protective variants exist. In addition, if subtle increases in UPR signaling activity enhance risk, this could mean that subtle inhibition of activity by pharmacological intervention may be a viable approach. PERK and IRE1 are considered to be "druggable" and the list of small molecule inhibitors to target these UPR sensors is growing [62].

For IRE1, both RNase and kinase inhibitors have been developed that differentially affect the respective activities and the dimerization properties of IRE1. Advantage of just inhibiting the RNase may be that only the XBP-1 processing is inhibited, whereas phosphorylation of putative other substrates of the IRE1 kinase and its dimerization are not affected [20, 85]. Type I kinase inhibitors inhibit autophosphorylation, but stimulate RNase activity, which may be useful for research, but not for clinical development [117]. Type II inhibitors inhibit both kinase and RNase activities and thus effectively block all signaling via IRE1 [27]. In models for ER stress-mediated degeneration the type II IRE1 inhibitor KIRA6 promotes cell survival [27].

Targeting of the PERK/eIF2 $\alpha$ pathway has received a lot of attention the last couple of years (Table 2). An early breakthrough was the compound Salubrinal, which targets the regulatory subunits of the eIF $2 \alpha$ protein phosphatase 1c (PP1c) [7]. Salubrinal was shown to ameliorate the neurodegenerative phenotype in a mouse model for ALS [88]. The drug Guanabenz, which is an $\alpha_{2}$-adrenergic receptor agonist used to treat hypertension, was demonstrated to selectively inhibit the stress-induced $\operatorname{eIF} 2 \alpha$ protein phosphatase regulatory subunit 15 A (PPP1R15A; a.k.a. GADD34, growth arrest and DNA damage-inducible protein 34) that forms a complex with PP1c [110], whereas Salubrinal also targets the constitutive PPP1R15B-PP1c complex. Guanabenz therefore does not completely inhibit the dephosphorylation of eIF $2 \alpha$. Guanabenz was beneficial in a SOD1 as well as a TDP-43 transgenic mouse model $[112,118]$.

Sephin1, a derivative of Guanabenz without its hypotensive action, was recently demonstrated to prevent neurodegeneration in a mouse model for ALS (SOD1 G93A) as well as neuronal loss in a model for the demyelinating peripheral neuropathy Charcot-Marie-Tooth disease type 1B [21]. For treatment of a neurodegenerative process that is ongoing, however, this may be different. The synaptic loss and neurodegeneration in animal models for prion disease and $\mathrm{A} \beta$ pathology were attributed to chronic inhibition of translation by eIF2 $\alpha$ phosphorylation [60, 64, 65]. Deletion of the PERK gene restores the translational defect and rescues the neurodegenerative phenotype [60, $65]$. The rescue in the $A \beta$ model is more difficult to interpret than the effects in the prion disease model, because of 
the direct effect of eIF2 $\alpha$ phosphorylation on BACE1 and $A \beta$. In addition, the effect in the $A \beta$ model is more related to eIF2 $\alpha$ than PERK, because deletion of GCN2 (another eIF $2 \alpha$ kinase) has the same effect. In the prion disease model, the interventions were initiated when pathology was already accumulating and eIF $2 \alpha$ phosphorylation was persistent. In such a pathological state, a treatment that prolongs eIF2 $\alpha$ phosphorylation is likely to make things worse. Indeed, in this study, decreasing eIF $2 \alpha$ dephosphorylation by Salubrinal worsened the phenotype, whereas increasing the eIF2 $\alpha$ dephosphorylation by overexpression of the induced phosphatase subunit PPP1R15A/GADD34 was beneficial. Another factor that may determine whether stimulation or inhibition eIF $2 \alpha$ phosphorylation is preferred is the subcellular localization of the accumulating proteins. Reduction of synthesis of proteins that accumulate in the ER may be beneficial, whereas inhibition of synthesis of cytoplasmic proteins may only lead to further synaptic loss and neurodegeneration. With the development of GSK2606414, an ATP competitive small molecule inhibitor of the PERK kinase activity, pharmacological intervention upstream in the PERK signaling pathway became feasible [3]. Treatment with the PERK inhibitor ameliorated neurodegeneration similar to the genetic interventions in the PERK pathway [64]. This provides an interesting proof of concept for involvement of PERK, however, inhibition of PERK is associated with severe pancreas pathology, as was also observed in the PERK knockout mouse [31, 129]. More recently, ISRIB (ISR Inhibitor B) was identified, which targets the translational arrest downstream of eIF $2 \alpha$ and thus circumvents PERK [96, 97]. It was demonstrated to act at the level of the exchange factor eIF2 $\beta$ and has positive effects on memory formation [93]. In the prion disease mouse model, ISRIB was indeed reported to ameliorate pathology. Although somewhat less effective than the PERK inhibitor in protection against neurodegeneration ISRIB showed strongly reduced pancreatic toxicity [28]. It is important to note that all treatments that target downstream of PERK are not UPR specific, but will affect the ISR in general.

The UPR is a homeostatic stress response. This implies that it is heavily regulated via positive and negative feedback loops. There is crosstalk between the three signaling pathways, so modulation of one pathway will affect signaling through the other two pathways as well. In a simple metaphor, this compares to the inhibition of water to flow through a tube on one end, which increases pressure elsewhere in the tube. Therefore, inhibition of one pathway may in fact increase signaling through one of the other pathways. For example, deletion of PERK results in increased activity of IRE1 $\alpha$ [31]. The connection between the site of intervention and the effect on the neurodegenerative process is therefore not always direct. This is not necessarily negative, an example of that is demonstrated in mice deficient for XBP-1 [37]. It was expected that incapacity to activate the XBP-1 transcriptional response would worsen the phenotype of a SOD1 mouse model for fALS. In contrast, it was shown to provide protection in this neurodegenerative model. This was attributed to increased autophagic clearance of SOD1 aggregates. It is tempting to speculate that inhibition of the IRE1 pathway results in increased signaling via the PERK and ATF6 pathways as both pathways, predominantly PERK, were shown to activate autophagy $[99,116]$. In a mHtt transgenic model for $\mathrm{HD}$, the deletion of XBP-1 was also found to be protective and accompanied by increased autophagic clearance of the aggregates [114]. However, in this model deletion of ATF4 alone had no effect on pathology. Instead, the findings suggested the activation of the Forkhead box O1 transcription factor. In addition, the HD model mice showed activation of the IRE1 pathway only, indicating it was different from canonical UPR activation to start with. Also in the studies addressing deletion and inhibition of PERK in neurodegenerative mouse models, there was no clear evidence of canonical UPR activation [60, 64, 65]. In this respect, we should be aware of potential ER stress-independent functions of the major UPR factors as well.

\section{Concluding remarks and perspective}

Evidence for UPR activation can be found in patient brains as well as models of several neurodegenerative diseases. The list of small molecules that target the UPR is growing. It is however important to distinguish positive and negative effects of the UPR. This is complicated by the notion that the direction in which to interfere (stimulation or inhibition) may be strongly affected by the pathological state. Caution is therefore warranted to directly translate mechanistic observations in the physiology to an application in pathology, where the adaptive UPR may have turned maladaptive. For example, the PERK pathway is activated in several neurodegenerative diseases, in the presence or absence of activation of the other UPR pathways. The adaptive PERK pathway functions to restore ER proteostasis by reducing overall protein synthesis via phosphorylation of eIF2 $\alpha$ and increasing the expression of UPR responsive genes via the production of the transcription factor ATF4. PERK activation increases BACE levels and thus A $\beta$ formation. In addition, tau phosphorylation is increased if PERK is activated. The function of these transient events in the adaptive response is not fully elucidated. During prolonged UPR activation, however, aberrant $\mathrm{A} \beta$ and tau proteins will accumulate which will facilitate pathology and in turn may contribute to UPR activity directly or indirectly in a vicious cycle. In addition, the persistent inhibition of 


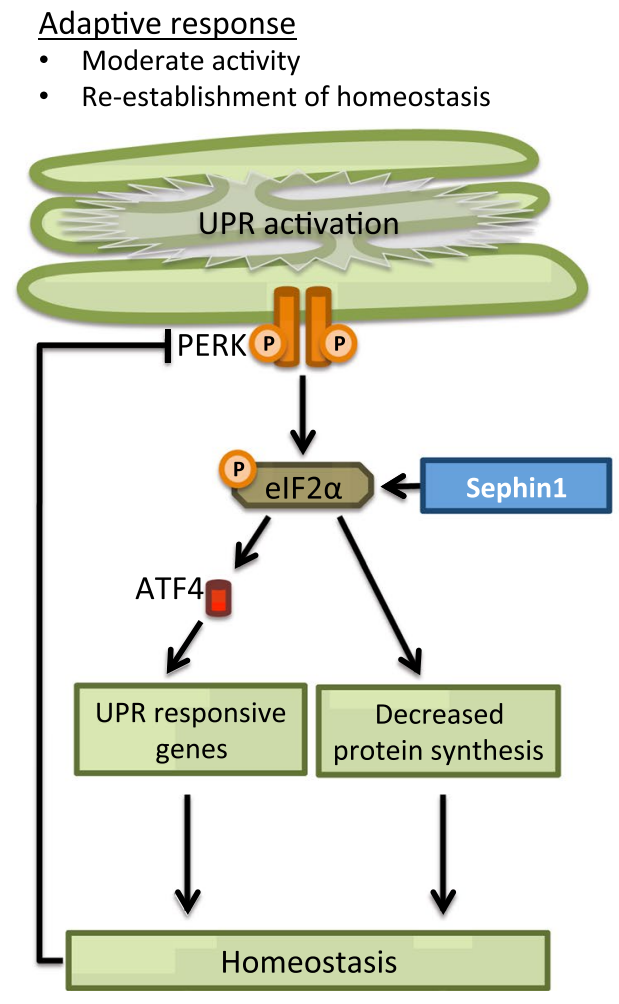

Fig. 3 The adaptive and maladaptive PERK pathway in neurodegenerative disease. In several neurodegenerative diseases, the PERK pathway is activated. The adaptive PERK pathway (left) functions to restore ER proteostasis. In contrast, in pathology (right) prolonged activation in neurodegenerative disease leads to loss of regulatory feedback and turns the adaptive UPR maladaptive, leading to accumulation of aberrant $A \beta$ en tau proteins and loss of synaptic pro-

protein translation results in loss of synaptic proteins that are essential for neuronal function. The prolonged UPR activation in the pathological state turns the adaptive UPR maladaptive (Fig. 3). This has important implications when using intervention in this pathway as therapeutic strategy. For example, prolonged phosphorylation of eIF $2 \alpha$ by Guanabenz or Sephin1 may be beneficial in prevention paradigms. However, in a pathological state with persistent eIF $2 \alpha$ phosphorylation at the start of treatment this may take a turn for the worse and inhibition of the pathway is preferred, however, ISR activators like sephin1 may be beneficial in case of accumulation of ER retained proteins.

Better understanding of the pathological state is pivotal to make a next step in UPR targeting for treatment of neurodegeneration. This will involve more precise characterization of the nature of the disturbance in the different pathways, for example, delineation of the involvement of GVD. In addition, new insights in the pathogenesis of neurodegenerative diseases like the spreading of pathological proteins will have to be incorporated into the bigger picture. These are a few of the issues that need to be addressed in the coming decade of UPR research in neurodegeneration.

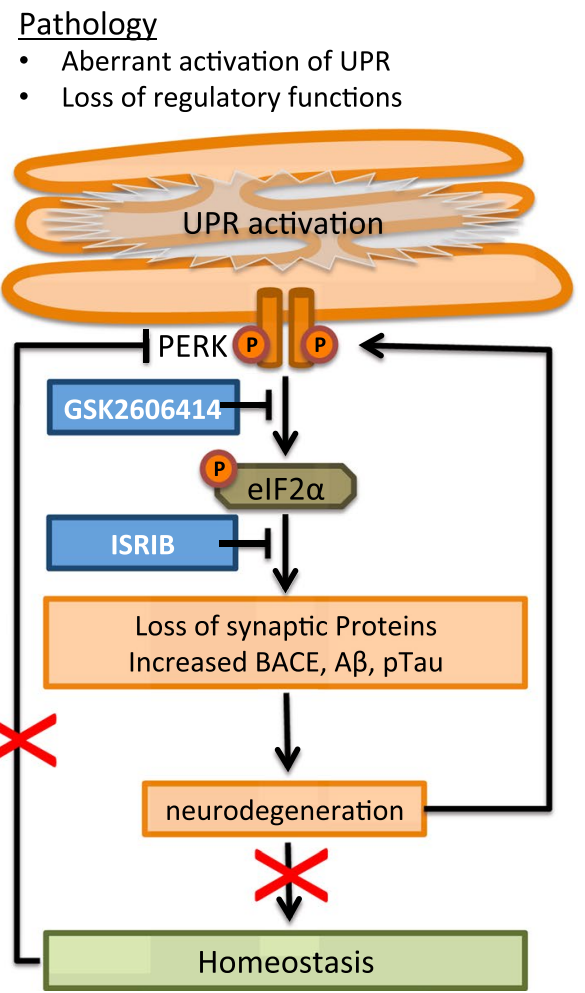

teins. It may be beneficial to stimulate the PERK pathway (e.g., by Sephin1) in the adaptive state, however, this may worsen the situation in the pathological state. Inhibition (e.g., by GSK2606414 or ISRIB) rather than stimulation of the pathway may therefore be beneficial for neurodegenerative diseases associated with persistent UPR activation. See text for further details

Acknowledgments We would like to dedicate this paper to Prof. Piet Eikelenboom, for his endless support, inspiration and still ongoing discussions. We thank all scientists who work in the field of UPR and neurodegeneration and apologize for not being able to cite them all. We thank our lab members, collaborators and funding organizations who contributed to our UPR research over the years. We thank the Netherlands Brain Bank and all the people who generously donated their brain for scientific research and without whom neuropathological research would not be possible.

Open Access This article is distributed under the terms of the Creative Commons Attribution 4.0 International License (http://creativecommons.org/licenses/by/4.0/), which permits unrestricted use, distribution, and reproduction in any medium, provided you give appropriate credit to the original author(s) and the source, provide a link to the Creative Commons license, and indicate if changes were made.

\section{References}

1. Abisambra JF, Jinwal UK, Blair LJ, O'Leary JC III, Li Q, Brady S, Wang L, Guidi CE, Zhang B, Nordhues BA, Cockman M, Suntharalingham A, Li P, Jin Y, Atkins CA, Dickey CA (2013) Tau accumulation activates the unfolded protein response by impairing endoplasmic reticulum-associated 
degradation. J Neurosci 33:9498-9507. doi:10.1523/ JNEUROSCI.5397-12.2013

2. Atkin JD, Farg MA, Walker AK, McLean C, Tomas D, Horne MK (2008) Endoplasmic reticulum stress and induction of the unfolded protein response in human sporadic amyotrophic lateral sclerosis. Neurobiol Dis 30:400-407. doi:10.1016/j. nbd.2008.02.009

3. Axten JM, Medina JR, Feng Y, Shu A, Romeril SP, Grant SW, Li WH, Heerding DA, Minthorn E, Mencken T, Atkins C, Liu Q, Rabindran S, Kumar R, Hong X, Goetz A, Stanley T, Taylor JD, Sigethy SD, Tomberlin GH, Hassell AM, Kahler KM, Shewchuk LM, Gampe RT (2012) Discovery of 7-methyl-5(1-\{[3-(trifluoromethyl)phenyl]acetyl \}-2,3-dihydro-1H-indol5-yl)-7H-p yrrolo[2,3-d]pyrimidin-4-amine (GSK2606414), a potent and selective first-in-class inhibitor of protein kinase $\mathrm{R}$ (PKR)-like endoplasmic reticulum kinase (PERK). J Med Chem 55:7193-7207. doi:10.1021/jm300713s

4. Ball MJ, Lo P (1977) Granulovacuolar degeneration in the ageing brain and in dementia. J Neuropathol Exp Neurol 36:474-487

5. Bernales S, McDonald KL, Walter P (2006) Autophagy counterbalances endoplasmic reticulum expansion during the unfolded protein response. PLoS Biol 4:e423

6. Bernales S, Schuck S, Walter P (2007) ER-phagy: selective autophagy of the endoplasmic reticulum. Autophagy 3:285-287

7. Boyce M, Bryant KF, Jousse C, Long K, Harding HP, Scheuner D, Kaufman RJ, Ma D, Coen DM, Ron D, Yuan J (2005) A selective inhibitor of eIF2alpha dephosphorylation protects cells from ER stress. Science 307:935-939

8. Braak H, Braak E (1991) Neuropathological stageing of Alzheimer-related changes. Acta Neuropathol 82:239-59

9. Braak H, Del Tredici K, Rub U, de Vos RA, Jansen Steur EN, Braak E (2003) Staging of brain pathology related to sporadic Parkinson's disease. Neurobiol Aging 24:197-211

10. Bruijn LI, Miller TM, Cleveland DW (2004) Unraveling the mechanisms involved in motor neuron degeneration in ALS. Annu Rev Neurosci 27:723-749. doi:10.1146/annurev. neuro.27.070203.144244

11. Calfon M, Zeng H, Urano F, Till JH, Hubbard SR, Harding HP, Clark SG, Ron D (2002) IRE1 couples endoplasmic reticulum load to secretory capacity by processing the XBP-1 mRNA. Nature 415:92-96. doi:10.1038/415092a

12. Carnemolla A, Fossale E, Agostoni E, Michelazzi S, Calligaris R, De ML, Del SG, MacDonald ME, Persichetti F (2009) Rrs1 is involved in endoplasmic reticulum stress response in Huntington disease. J Biol Chem 284:18167-18173. doi:10.1074/ jbc.M109.018325

13. Chafekar SM, Baas F, Scheper W (2008) Oligomer-specific Abeta toxicity in cell models is mediated by selective uptake. Biochim Biophys Acta 1782:523-531

14. Chafekar SM, Hoozemans JJ, Zwart R, Baas F, Scheper W (2007) Abeta 1-42 induces mild endoplasmic reticulum stress in an aggregation state-dependent manner. Antioxid Redox Signal 9:2245-2254

15. Chang RC, Suen KC, Ma CH, Elyaman W, Ng HK, Hugon J (2002) Involvement of double-stranded RNA-dependent protein kinase and phosphorylation of eukaryotic initiation factor-2alpha in neuronal degeneration. J Neurochem 83:1215-1225

16. Chung CY, Khurana V, Auluck PK, Tardiff DF, Mazzulli JR, Soldner F, Baru V, Lou Y, Freyzon Y, Cho S, Mungenast AE, Muffat J, Mitalipova M, Pluth MD, Jui NT, Schule B, Lippard SJ, Tsai LH, Krainc D, Buchwald SL, Jaenisch R, Lindquist S (2013) Identification and rescue of alpha-synuclein toxicity in Parkinson patient-derived neurons. Science 342:983-987. doi:10.1126/science. 1245296
17. Cooper AA, Gitler AD, Cashikar A, Haynes CM, Hill KJ, Bhullar B, Liu K, Xu K, Strathearn KE, Liu F, Cao S, Caldwell KA, Caldwell GA, Marsischky G, Kolodner RD, Labaer J, Rochet JC, Bonini NM, Lindquist S (2006) Alpha-synuclein blocks ER-Golgi traffic and Rab1 rescues neuron loss in Parkinson's models. Science 313:324-328

18. Cox JS, Shamu CE, Walter P (1993) Transcriptional induction of genes encoding endoplasmic reticulum resident proteins requires a transmembrane protein kinase. Cell 73:1197-1206

19. Cox JS, Walter P (1996) A novel mechanism for regulating activity of a transcription factor that controls the unfolded protein response. Cell 87:391-404

20. Cross BC, Bond PJ, Sadowski PG, Jha BK, Zak J, Goodman JM, Silverman RH, Neubert TA, Baxendale IR, Ron D, Harding HP (2012) The molecular basis for selective inhibition of unconventional mRNA splicing by an IRE1-binding small molecule. Proc Natl Acad Sci 109:E869-E878. doi:10.1073/ pnas. 1115623109

21. Das I, Krzyzosiak A, Schneider K, Wrabetz L, D'Antonio M, Barry N, Sigurdardottir A, Bertolotti A (2015) Preventing proteostasis diseases by selective inhibition of a phosphatase regulatory subunit. Science 348:239-242. doi:10.1126/science. aaa4484

22. DeJesus-Hernandez M, Mackenzie IR, Boeve BF, Boxer AL, Baker M, Rutherford NJ, Nicholson AM, Finch NA, Flynn H, Adamson J, Kouri N, Wojtas A, Sengdy P, Hsiung GY, Karydas A, Seeley WW, Josephs KA, Coppola G, Geschwind DH, Wszolek ZK, Feldman H, Knopman DS, Petersen RC, Miller BL, Dickson DW, Boylan KB, Graff-Radford NR, Rademakers R (2011) Expanded GGGGCC hexanucleotide repeat in noncoding region of C9ORF72 causes chromosome 9p-linked FTD and ALS. Neuron 72:245-256. doi:10.1016/j. neuron.2011.09.011

23. Delepine M, Nicolino M, Barrett T, Golamaully M, Lathrop GM, Julier C (2000) EIF2AK3, encoding translation initiation factor 2-alpha kinase 3, is mutated in patients with Wolcott-Rallison syndrome. Nat Genet 25:406-409. doi:10.1038/78085

24. Ding WX, Ni HM, Gao W, Hou YF, Melan MA, Chen X, Stolz DB, Shao ZM, Yin XM (2007) Differential effects of endoplasmic reticulum stress-induced autophagy on cell survival. J Biol Chem 282:4702-4710

25. Donnelly N, Gorman AM, Gupta S, Samali A (2013) The eIF2alpha kinases: their structures and functions. Cell Mol Life Sci 70:3493-3511. doi:10.1007/s00018-012-1252-6

26. Fernandez-Fernandez MR, Ferrer I, Lucas JJ (2011) Impaired ATF6alpha processing, decreased Rheb and neuronal cell cycle re-entry in Huntington's disease. Neurobiol Dis 41:23-32. doi:10.1016/j.nbd.2010.08.014

27. Ghosh R, Wang L, Wang ES, Perera BG, Igbaria A, Morita S, Prado K, Thamsen M, Caswell D, Macias H, Weiberth KF, Gliedt MJ, Alavi MV, Hari SB, Mitra AK, Bhhatarai B, Schurer SC, Snapp EL, Gould DB, German MS, Backes BJ, Maly DJ, Oakes SA, Papa FR (2014) Allosteric inhibition of the IRE1alpha RNase preserves cell viability and function during endoplasmic reticulum stress. Cell 158:534-548. doi:10.1016/j. cell.2014.07.002

28. Halliday M, Radford H, Sekine Y, Moreno J, Verity N, le Quesne J, Ortori CA, Barrett DA, Fromont C, Fischer PM, Harding HP, Ron D, Mallucci GR (2015) Partial restoration of protein synthesis rates by the small molecule ISRIB prevents neurodegeneration without pancreatic toxicity. Cell Death Dis. doi:10.1038/cddis.2015.49

29. Hamos JE, Oblas B, Pulaski-Salo D, Welch WJ, Bole DG, Drachman DA (1991) Expression of heat shock proteins in Alzheimer's disease. Neurology 41:345-350 
30. Han D, Lerner AG, Vande WL, Upton JP, Xu W, Hagen A, Backes BJ, Oakes SA, Papa FR (2009) IRE1alpha kinase activation modes control alternate endoribonuclease outputs to determine divergent cell fates. Cell 138:562-575. doi:10.1016/j. cell.2009.07.017

31. Harding HP, Zeng H, Zhang Y, Jungries R, Chung P, Plesken H, Sabatini DD, Ron D (2001) Diabetes mellitus and exocrine pancreatic dysfunction in perk- $/-$ mice reveals a role for translational control in secretory cell survival. Mol Cell 7:1153-1163

32. Harding HP, Zhang Y, Bertolotti A, Zeng H, Ron D (2000) Perk is essential for translational regulation and cell survival during the unfolded protein response. Mol Cell 5:897-904

33. Harding HP, Zhang Y, Ron D (1999) Protein translation and folding are coupled by an endoplasmic-reticulum-resident kinase. Nature 397:271-274. doi:10.1038/16729

34. Haze K, Yoshida H, Yanagi H, Yura T, Mori K (1999) Mammalian transcription factor ATF6 is synthesized as a transmembrane protein and activated by proteolysis in response to endoplasmic reticulum stress. Mol Biol Cell 10:3787-3799

35. Hetz C, Glimcher LH (2009) Fine-tuning of the unfolded protein response: assembling the IRE1alpha interactome. Mol Cell 35:551-561. doi:10.1016/j.molcel.2009.08.021

36. Hetz C, Russelakis-Carneiro M, Maundrell K, Castilla J, Soto C (2003) Caspase-12 and endoplasmic reticulum stress mediate neurotoxicity of pathological prion protein. EMBO J 22:5435-5445

37. Hetz C, Thielen P, Matus S, Nassif M, Court F, Kiffin R, Martinez G, Cuervo AM, Brown RH, Glimcher LH (2009) XBP-1 deficiency in the nervous system protects against amyotrophic lateral sclerosis by increasing autophagy. Genes Dev 23:22942306. doi:10.1101/gad.1830709

38. Ho YS, Yang X, Lau JC, Hung CH, Wuwongse S, Zhang Q, Wang J, Baum L, So KF, Chang RC (2012) Endoplasmic reticulum stress induces tau pathology and forms a vicious cycle: implication in Alzheimer's disease pathogenesis. J Alzheimers Dis 28:839-854. doi:10.3233/JAD-2011-111037

39. Höglinger GU, Melhem NM, Dickson DW, Sleiman PM, Wang LS, Klei L, Rademakers R, de Silva R, Litvan I, Riley DE, van Swieten JC, Heutink P, Wszolek ZK, Uitti RJ, Vandrovcova J, Hurtig HI, Gross RG, Maetzler W, Goldwurm S, Tolosa E, Borroni B, Pastor P, PSP Genetics Study Group, Cantwell LB, Han MR, Dillman A, van der Brug MP, Gibbs JR, Cookson MR, Hernandez DG, Singleton AB, Farrer MJ, Yu CE, Golbe LI, Revesz T, Hardy J, Lees AJ, Devlin B, Hakonarson H, Müller U, Schellenberg GD (2011) Identification of common variants influencing risk of the tauopathy progressive supranuclear palsy. Nat Genet 43:699-705. doi:10.1038/ng.859

40. Hoozemans JJ, Van Haastert ES, Eikelenboom P, de Vos RA, Rozemuller JM, Scheper W (2007) Activation of the unfolded protein response in Parkinson's disease. Biochem Biophys Res Commun 354:707-711

41. Hoozemans JJ, Van Haastert ES, Nijholt DA, Rozemuller AJ, Eikelenboom P, Scheper W (2009) The unfolded protein response is activated in pretangle neurons in Alzheimer's disease hippocampus. Am J Pathol 174:1241-1251. doi:10.2353/ ajpath.2009.080814

42. Hoozemans JJ, Veerhuis R, Van Haastert ES, Rozemuller JM, Baas F, Eikelenboom P, Scheper W (2005) The unfolded protein response is activated in Alzheimer's disease. Acta Neuropathol (Berl) 110:165-172

43. Hou HL, Shen YX, Zhu HY, Sun H, Yan XB, Fang H, Zhou JN (2006) Alterations of hHrdl expression are related to hyperphosphorylated tau in the hippocampus in Alzheimer's disease. J Neurosci Res 84:1862-1870. doi:10.1002/jnr.21081

44. Ilieva EV, Ayala V, Jove M, Dalfo E, Cacabelos D, Povedano M, Bellmunt MJ, Ferrer I, Pamplona R, Portero-Otin M (2007)
Oxidative and endoplasmic reticulum stress interplay in sporadic amyotrophic lateral sclerosis. Brain 130:3111-3123. doi:10.1093/brain/awm190

45. Ito Y, Yamada M, Tanaka H, Aida K, Tsuruma K, Shimazawa M, Hozumi I, Inuzuka T, Takahashi H, Hara H (2009) Involvement of CHOP, an ER-stress apoptotic mediator, in both human sporadic ALS and ALS model mice. Neurobiol Dis 36:470-476. doi:10.1016/j.nbd.2009.08.013

46. Iwakoshi NN, Lee AH, Vallabhajosyula P, Otipoby KL, Rajewsky K, Glimcher LH (2003) Plasma cell differentiation and the unfolded protein response intersect at the transcription factor XBP-1. Nat Immunol 4:321-329. doi:10.1038/ni907

47. Kakiuchi C, Iwamoto K, Ishiwata M, Bundo M, Kasahara T, Kusumi I, Tsujita T, Okazaki Y, Nanko S, Kunugi H, Sasaki T, Kato T (2003) Impaired feedback regulation of XBP1 as a genetic risk factor for bipolar disorder. Nat Genet 35:171-175. doi:10.1038/ng 1235

48. Katayama T, Imaizumi K, Sato N, Miyoshi K, Kudo T, Hitomi J, Morihara T, Yoneda T, Gomi F, Mori Y, Nakano Y, Takeda J, Tsuda T, Itoyama Y, Murayama O, Takashima A, St GeorgeHyslop P, Takeda M, Tohyama M (1999) Presenilin-1 mutations downregulate the signalling pathway of the unfolded-protein response. Nat Cell Biol 1:479-485

49. Kiskinis E, Sandoe J, Williams LA, Boulting GL, Moccia R, Wainger BJ, Han S, Peng T, Thams S, Mikkilineni S, Mellin C, Merkle FT, Davis-Dusenbery BN, Ziller M, Oakley D, Ichida J, Di CS, Atwater N, Maeder ML, Goodwin MJ, Nemesh J, Handsaker RE, Paull D, Noggle S, McCarroll SA, Joung JK, Woolf CJ, Brown RH, Eggan K (2014) Pathways disrupted in human ALS motor neurons identified through genetic correction of mutant SOD1. Cell Stem Cell 14:781-795. doi:10.1016/j. stem.2014.03.004

50. Kohler C, Dinekov M, Gotz J (2014) Granulovacuolar degeneration and unfolded protein response in mouse models of tauopathy and Abeta amyloidosis. Neurobiol Dis 71:169-179. doi:10.1016/j.nbd.2014.07.006

51. Kondo T, Asai M, Tsukita K, Kutoku Y, Ohsawa Y, Sunada Y, Imamura K, Egawa N, Yahata N, Okita K, Takahashi K, Asaka I, Aoi T, Watanabe A, Watanabe K, Kadoya C, Nakano R, Watanabe D, Maruyama K, Hori O, Hibino S, Choshi T, Nakahata T, Hioki H, Kaneko T, Naitoh M, Yoshikawa K, Yamawaki S, Suzuki S, Hata R, Ueno S, Seki T, Kobayashi K, Toda T, Murakami K, Irie K, Klein WL, Mori H, Asada T, Takahashi R, Iwata N, Yamanaka S, Inoue H (2013) Modeling Alzheimer's disease with iPSCs reveals stress phenotypes associated with intracellular Abeta and differential drug responsiveness. Cell Stem Cell 12:487-496. doi:10.1016/j.stem.2013.01.009

52. Kozutsumi Y, Segal M, Normington K, Gething MJ, Sambrook $\mathrm{J}$ (1988) The presence of malfolded proteins in the endoplasmic reticulum signals the induction of glucose-regulated proteins. Nature 332:462-464. doi:10.1038/332462a0

53. Lee AS (1987) Coordinated regulation of a set of genes by glucose and calcium ionophores in mammalian cells. Trends Biochem Sci 12:20-23

54. Lee H, Noh JY, Oh Y, Kim Y, Chang JW, Chung CW, Lee ST, Kim M, Ryu H, Jung YK (2012) IRE1 plays an essential role in ER stress-mediated aggregation of mutant huntingtin via the inhibition of autophagy flux. Hum Mol Genet 21:101-114. doi: $10.1093 / \mathrm{hmg} / \mathrm{ddr} 445$

55. Lee K, Tirasophon W, Shen X, Michalak M, Prywes R, Okada T, Yoshida H, Mori K, Kaufman RJ (2002) IRE1-mediated unconventional mRNA splicing and S2P-mediated ATF6 cleavage merge to regulate XBP1 in signaling the unfolded protein response. Genes Dev 16:452-466

56. Lin L, Yang SS, Chu J, Wang L, Ning LN, Zhang T, Jiang Q, Tian Q, Wang JZ (2014) Region-specific expression of 
tau, amyloid-beta protein precursor, and synaptic proteins at physiological condition or under endoplasmic reticulum stress in rats. J Alzheimers Dis. doi:10.3233/JAD-140207 (831M243753684PJJ)

57. Liu J, Hoppman N, O'Connell JR, Wang H, Streeten EA, McLenithan JC, Mitchell BD, Shuldiner AR (2012) A functional haplotype in EIF2AK3, an ER stress sensor, is associated with lower bone mineral density. J Bone Miner Res 27:331341. doi:10.1002/jbmr.549

58. Liu QY, Yu JT, Miao D, Ma XY, Wang HF, Wang W, Tan L (2013) An exploratory study on STX6, MOBP, MAPT, and EIF2AK3 and late-onset Alzheimer's disease. Neurobiol Aging 34:1519.e13-1519.e17. doi:10.1016/j. neurobiolaging.2012.10.004

59. Liu SY, Wang W, Cai ZY, Lao LF, Chen ZW, Wang CY, Zhao B, Li KS (2013) Polymorphism-116C/G of human X-box-binding protein 1 promoter is associated with risk of Alzheimer's disease. CNS Neurosci Ther. doi:10.1111/cns.12064

60. Ma T, Trinh MA, Wexler AJ, Bourbon C, Gatti E, Pierre P, Cavener DR, Klann E (2013) Suppression of eIF2alpha kinases alleviates Alzheimer's disease-related plasticity and memory deficits. Nat Neurosci 16:1299-1305. doi:10.1038/nn.3486

61. Makioka K, Yamazaki T, Fujita Y, Takatama M, Nakazato Y, Okamoto K (2010) Involvement of endoplasmic reticulum stress defined by activated unfolded protein response in multiple system atrophy. J Neurol Sci 297:60-65. doi:10.1016/j. jns.2010.06.019

62. Maly DJ, Papa FR (2014) Druggable sensors of the unfolded protein response. Nat Chem Biol 10:892-901. doi:10.1038/ nchembio.1664

63. Maurel M, McGrath EP, Mnich K, Healy S, Chevet E, Samali A (2015) Controlling the unfolded protein response-mediated life and death decisions in cancer. Semin Cancer Biol. doi:10.1016/j.semcancer.2015.03.003

64. Moreno JA, Halliday M, Molloy C, Radford H, Verity N, Axten JM, Ortori CA, Willis AE, Fischer PM, Barrett DA, Mallucci GR (2013) Oral treatment targeting the unfolded protein response prevents neurodegeneration and clinical disease in prion-infected mice. Sci Transl Med 5:206ra138. doi:10.1126/ scitranslmed.3006767 (-5/206/206ra138)

65. Moreno JA, Radford H, Peretti D, Steinert JR, Verity N, Martin MG, Halliday M, Morgan J, Dinsdale D, Ortori CA, Barrett DA, Tsaytler P, Bertolotti A, Willis AE, Bushell M, Mallucci GR (2012) Sustained translational repression by eIF2alpha$\mathrm{P}$ mediates prion neurodegeneration. Nature 485:507-511. doi:10.1038/nature11058

66. Mori K, Ma W, Gething MJ, Sambrook J (1993) A transmembrane protein with a cdc2+/CDC28-related kinase activity is required for signaling from the ER to the nucleus. Cell 74:743-756

67. Mori K, Sant A, Kohno K, Normington K, Gething MJ, Sambrook JF (1992) A 22 bp cis-acting element is necessary and sufficient for the induction of the yeast KAR2 (BiP) gene by unfolded proteins. EMBO J 11:2583-2593

68. Nagata T, Ilieva H, Murakami T, Shiote M, Narai H, Ohta Y, Hayashi T, Shoji M, Abe K (2007) Increased ER stress during motor neuron degeneration in a transgenic mouse model of amyotrophic lateral sclerosis. Neurol Res 29:767-771. doi:10.1 179/016164107X229803

69. Nijholt DA, de Graaf TR, Van Haastert ES, Oliveira AO, Berkers CR, Zwart R, Ovaa H, Baas F, Hoozemans JJ, Scheper W (2011) Endoplasmic reticulum stress activates autophagy but not the proteasome in neuronal cells: implications for Alzheimer's disease. Cell Death Differ 18:1071-1081. doi:10.1038/ cdd.2010.176

70. Nijholt DA, Van Haastert ES, Rozemuller AJ, Scheper W, Hoozemans JJ (2012) The unfolded protein response is associated with early tau pathology in the hippocampus of tauopathies. J Pathol 226:693-702. doi:10.1002/path.3969

71. Niwa M, Sidrauski C, Kaufman RJ, Walter P (1999) A role for presenilin-1 in nuclear accumulation of Ire1 fragments and induction of the mammalian unfolded protein response. Cell 99:691-702

72. O'Connor T, Sadleir KR, Maus E, Velliquette RA, Zhao J, Cole SL, Eimer WA, Hitt B, Bembinster LA, Lammich S, Lichtenthaler SF, Hebert SS, De Strooper B, Haass C, Bennett DA, Vassar R (2008) Phosphorylation of the translation initiation factor eIF2alpha increases BACE1 levels and promotes amyloidogenesis. Neuron 60:988-1009

73. Ogata M, Hino S, Saito A, Morikawa K, Kondo S, Kanemoto S, Murakami T, Taniguchi M, Tanii I, Yoshinaga K, Shiosaka S, Hammarback JA, Urano F, Imaizumi K (2006) Autophagy is activated for cell survival after endoplasmic reticulum stress. Mol Cell Biol 26:9220-9231

74. Okamoto $\mathrm{K}$, Hirai S, Iizuka T, Yanagisawa T, Watanabe M (1991) Reexamination of granulovacuolar degeneration. Acta Neuropathol 82:340-345

75. Piccini A, Fassio A, Pasqualetto E, Vitali A, Borghi R, Palmieri D, Nacmias B, Sorbi S, Sitia R, Tabaton M (2004) Fibroblasts from FAD-linked presenilin 1 mutations display a normal unfolded protein response but overproduce Abeta42 in response to tunicamycin. Neurobiol Dis 15:380-386

76. Reimold AM, Etkin A, Clauss I, Perkins A, Friend DS, Zhang J, Horton HF, Scott A, Orkin SH, Byrne MC, Grusby MJ, Glimcher LH (2000) An essential role in liver development for transcription factor XBP-1. Genes Dev 14:152-157

77. Ren Y, Yang S, Xu S, Gao M, Huang W, Gao T, Fang Q, Quan C, Zhang C, Sun L, Liang Y, Han J, Wang Z, Zhang F, Zhou Y, Liu J, Zhang X (2009) Genetic variation of promoter sequence modulates XBP1 expression and genetic risk for vitiligo. PLoS Genet 5:e1000523. doi:10.1371/journal.pgen.1000523

78. Renton AE, Majounie E, Waite A, Simon-Sanchez J, Rollinson S, Gibbs JR, Schymick JC, Laaksovirta H, van Swieten JC, Myllykangas L, Kalimo H, Paetau A, Abramzon Y, Remes AM, Kaganovich A, Scholz SW, Duckworth J, Ding J, Harmer DW, Hernandez DG, Johnson JO, Mok K, Ryten M, Trabzuni D, Guerreiro RJ, Orrell RW, Neal J, Murray A, Pearson J, Jansen IE, Sondervan D, Seelaar H, Blake D, Young K, Halliwell N, Callister JB, Toulson G, Richardson A, Gerhard A, Snowden J, Mann D, Neary D, Nalls MA, Peuralinna T, Jansson L, Isoviita VM, Kaivorinne AL, Holtta-Vuori M, Ikonen E, Sulkava R, Benatar M, Wuu J, Chio A, Restagno G, Borghero G, Sabatelli M, Heckerman D, Rogaeva E, Zinman L, Rothstein JD, Sendtner M, Drepper C, Eichler EE, Alkan C, Abdullaev Z, Pack SD, Dutra A, Pak E, Hardy J, Singleton A, Williams NM, Heutink P, Pickering-Brown S, Morris HR, Tienari PJ, Traynor BJ (2011) A hexanucleotide repeat expansion in C9ORF72 is the cause of chromosome 9p21-linked ALS-FTD. Neuron 72:257-268. doi:10.1016/j.neuron.2011.09.010

79. Roussel BD, Kruppa AJ, Miranda E, Crowther DC, Lomas DA, Marciniak SJ (2013) Endoplasmic reticulum dysfunction in neurological disease. Lancet Neurol 12:105-118. doi:10.1016/ S1474-4422(12)70238-7

80. Ruggiano A, Foresti O, Carvalho P (2014) Quality control: ERassociated degradation: protein quality control and beyond. J Cell Biol 204:869-879. doi:10.1083/jcb.201312042

81. Rutkowski DT, Hegde RS (2010) Regulation of basal cellular physiology by the homeostatic unfolded protein response. J Cell Biol 189:783-794. doi:10.1083/jcb.201003138

82. Ryu EJ, Harding HP, Angelastro JM, Vitolo OV, Ron D, Greene LA (2002) Endoplasmic reticulum stress and the unfolded protein response in cellular models of Parkinson's disease. J Neurosci 22:10690-10698 
83. Saleh M, Mathison JC, Wolinski MK, Bensinger SJ, Fitzgerald P, Droin N, Ulevitch RJ, Green DR, Nicholson DW (2006) Enhanced bacterial clearance and sepsis resistance in caspase-12-deficient mice. Nature 440:1064-1068. doi:10.1038/ nature 04656

84. Saleh M, Vaillancourt JP, Graham RK, Huyck M, Srinivasula SM, Alnemri ES, Steinberg MH, Nolan V, Baldwin CT, Hotchkiss RS, Buchman TG, Zehnbauer BA, Hayden MR, Farrer LA, Roy S, Nicholson DW (2004) Differential modulation of endotoxin responsiveness by human caspase-12 polymorphisms. Nature 429:75-79. doi:10.1038/nature02451

85. Sanches M, Duffy NM, Talukdar M, Thevakumaran N, Chiovitti D, Canny MD, Lee K, Kurinov I, Uehling D, Al-awar R, Poda G, Prakesch M, Wilson B, Tam V, Schweitzer C, Toro A, Lucas JL, Vuga D, Lehmann L, Durocher D, Zeng Q, Patterson JB, Sicheri F (2014) Structure and mechanism of action of the hydroxy-aryl-aldehyde class of IRE1 endoribonuclease inhibitors. Nat Commun 5:4202. doi:10.1038/ncomms5202

86. Sasaki S (2010) Endoplasmic reticulum stress in motor neurons of the spinal cord in sporadic amyotrophic lateral sclerosis. J Neuropathol Exp Neurol 69:346-355. doi:10.1097/ NEN.0b013e3181d44992

87. Sato N, Urano F, Yoon Leem J, Kim SH, Li M, Donoviel D, Bernstein A, Lee AS, Ron D, Veselits ML, Sisodia SS, Thinakaran G (2000) Upregulation of $\mathrm{BiP}$ and CHOP by the unfolded-protein response is independent of presenilin expression. Nat Cell Biol 2:863-870

88. Saxena S, Cabuy E, Caroni P (2009) A role for motoneuron subtype-selective ER stress in disease manifestations of FALS mice. Nat Neurosci 12:627-636. doi:10.1038/nn.2297

89. Scheper W, Hoozemans JJ (2013) A new PERKspective on neurodegeneration. Sci Transl Med 5:206fs37. doi:10.1126/scitranslmed.3007641 (-5/206/206fs37)

90. Scheper W, Nijholt DA, Hoozemans JJ (2011) The unfolded protein response and proteostasis in Alzheimer disease: preferential activation of autophagy by endoplasmic reticulum stress. Autophagy 7:910-911

91. Scheuner D, Kaufman RJ (2008) The unfolded protein response: a pathway that links insulin demand with beta-cell failure and diabetes. Endocr Rev 29:317-333. doi:10.1210/ er.2007-0039

92. Schwenk BM, Edbauer D (2014) The ER under rapid fire. EMBO J 33:1195-1197. doi:10.1002/embj.201488692

93. Sekine Y, Zyryanova A, Crespillo-Casado A, Fischer PM, Harding HP, Ron D (2015) Mutations in a translation initiation factor identify the target of a memory-enhancing compound. Science 348:1027-1030. doi:10.1126/science.aaa6986

94. Shamu CE, Walter P (1996) Oligomerization and phosphorylation of the Ire1p kinase during intracellular signaling from the endoplasmic reticulum to the nucleus. EMBO $\mathbf{J}$ 15:3028-3039

95. Shi Y, Vattem KM, Sood R, An J, Liang J, Stramm L, Wek RC (1998) Identification and characterization of pancreatic eukaryotic initiation factor 2 alpha-subunit kinase, PEK, involved in translational control. Mol Cell Biol 18:7499-7509

96. Sidrauski C, Acosta-Alvear D, Khoutorsky A, Vedantham P, Hearn BR, Li H, Gamache K, Gallagher CM, Ang KK, Wilson C, Okreglak V, Ashkenazi A, Hann B, Nader K, Arkin MR, Renslo AR, Sonenberg N, Walter P (2013) Pharmacological brake-release of mRNA translation enhances cognitive memory. eLife 2:e00498. doi:10.7554/eLife.00498

97. Sidrauski C, McGeachy AM, Ingolia NT, Walter P (2015) The small molecule ISRIB reverses the effects of eIF2alpha phosphorylation on translation and stress granule assembly. eLife 4: 05033. doi:10.7554/eLife.05033
98. Sidrauski C, Walter P (1997) The transmembrane kinase Ire1p is a site-specific endonuclease that initiates mRNA splicing in the unfolded protein response. Cell 90:1031-1039

99. Srikanth NS, Seth PK (1990) Alterations in xenobiotic metabolizing enzymes in brain and liver of rats coexposed to endosulfan and malathion. J Appl Toxicol 10:157-160

100. Stefanis L, Larsen KE, Rideout HJ, Sulzer D, Greene LA (2001) Expression of A53T mutant but not wild-type alphasynuclein in PC12 cells induces alterations of the ubiquitindependent degradation system, loss of dopamine release, and autophagic cell death. J Neurosci 21:9549-9560

101. Steiner H, Winkler E, Shearman MS, Prywes R, Haass C (2001) Endoproteolysis of the ER stress transducer ATF6 in the presence of functionally inactive presenilins. Neurobiol Dis 8:717-722

102. Stoveken BJ (2013) Tau pathology as a cause and consequence of the UPR. J Neurosci 33:14285-14287. doi:10.1523/ JNEUROSCI.2961-13.2013

103. Stutzbach LD, Xie SX, Naj AC, Albin R, Gilman S, Lee VM, Trojanowski JQ, Devlin B, Schellenberg GD (2013) The unfolded protein response is activated in disease-affected brain regions in progressive supranuclear palsy and Alzheimer's disease. Acta Neuropathol Commun 1:31. doi:10.1186/2051-59601-31 (-2051-5960-1-31)

104. Subjeck JR, Shyy TT (1986) Stress protein systems of mammalian cells. Am J Physiol 250:C1-C17

105. Suen KC, Lin KF, Elyaman W, So KF, Chang RC, Hugon J (2003) Reduction of calcium release from the endoplasmic reticulum could only provide partial neuroprotection against beta-amyloid peptide toxicity. J Neurochem 87:1413-1426

106. Taylor JP, Hardy J, Fischbeck KH (2002) Toxic proteins in neurodegenerative disease. Science 296:1991-1995

107. Thal DR, Del TK, Ludolph AC, Hoozemans JJ, Rozemuller AJ, Braak H, Knippschild U (2011) Stages of granulovacuolar degeneration: their relation to Alzheimer's disease and chronic stress response. Acta Neuropathol 122:577-589. doi:10.1007/ s00401-011-0871-6

108. Thal DR, Walter J, Saido TC, Fandrich M (2015) Neuropathology and biochemistry of Abeta and its aggregates in Alzheimer's disease. Acta Neuropathol 129:167-182. doi:10.1007/ s00401-014-1375-y

109. Tirasophon W, Welihinda AA, Kaufman RJ (1998) A stress response pathway from the endoplasmic reticulum to the nucleus requires a novel bifunctional protein kinase/endoribonuclease (Irelp) in mammalian cells. Genes Dev 12:1812-1824

110. Tsaytler P, Harding HP, Ron D, Bertolotti A (2011) Selective inhibition of a regulatory subunit of protein phosphatase 1 restores proteostasis. Science 332:91-94. doi:10.1126/ science. 1201396

111. Unterberger U, Hoftberger R, Gelpi E, Flicker H, Budka H, Voigtlander T (2006) Endoplasmic reticulum stress features are prominent in Alzheimer disease but not in prion diseases in vivo. J Neuropathol Exp Neurol 65:348-357

112. Vaccaro A, Patten SA, Aggad D, Julien C, Maios C, Kabashi E, Drapeau P, Parker JA (2013) Pharmacological reduction of ER stress protects against TDP-43 neuronal toxicity in vivo. Neurobiol Dis 55:64-75. doi:10.1016/j.nbd.2013.03.015

113. van der Harg JM, Nölle A, Zwart R, Boerema AS, Van Haastert ES, Strijkstra AM, Hoozemans JJ, Scheper W (2014) The unfolded protein response mediates reversible tau phosphorylation induced by metabolic stress. Cell Death Dis 5:e1393. doi:10.1038/cddis.2014.354

114. Vidal RL, Figueroa A, Court FA, Thielen P, Molina C, Wirth C, Caballero B, Kiffin R, Segura-Aguilar J, Cuervo AM, Glimcher LH, Hetz C (2012) Targeting the UPR transcription factor 
XBP1 protects against Huntington's disease through the regulation of FoxO1 and autophagy. Hum Mol Genet 21:2245-2262. doi:10.1093/hmg/dds040

115. Wainger BJ, Kiskinis E, Mellin C, Wiskow O, Han SS, Sandoe J, Perez NP, Williams LA, Lee S, Boulting G, Berry JD, Brown RH Jr, Cudkowicz ME, Bean BP, Eggan K, Woolf CJ (2014) Intrinsic membrane hyperexcitability of amyotrophic lateral sclerosis patient-derived motor neurons. Cell Rep 7:1-11. doi:10.1016/j.celrep.2014.03.019

116. Wang J, Kang R, Huang H, Xi X, Wang B, Wang J, Zhao Z (2014) Hepatitis C virus core protein activates autophagy through EIF2AK3 and ATF6 UPR pathway-mediated MAP1LC3B and ATG12 expression. Autophagy 10:766-784. doi:10.4161/auto.27954

117. Wang L, Perera BG, Hari SB, Bhhatarai B, Backes BJ, Seeliger MA, Schurer SC, Oakes SA, Papa FR, Maly DJ (2012) Divergent allosteric control of the IRE1alpha endoribonuclease using kinase inhibitors. Nat Chem Biol 8:982-989. doi:10.1038/ nchembio.1094

118. Wang L, Popko B, Tixier E, Roos RP (2014) Guanabenz, which enhances the unfolded protein response, ameliorates mutant SOD1-induced amyotrophic lateral sclerosis. Neurobiol Dis 71:317-324. doi:10.1016/j.nbd.2014.08.010

119. Wang XZ, Harding HP, Zhang Y, Jolicoeur EM, Kuroda M, Ron D (1998) Cloning of mammalian Ire1 reveals diversity in the ER stress responses. EMBO J 17:5708-5717. doi:10.1093/ emboj/17.19.5708

120. Welihinda AA, Kaufman RJ (1996) The unfolded protein response pathway in Saccharomyces cerevisiae. Oligomerization and trans-phosphorylation of Ire1p (Ern $1 p)$ are required for kinase activation. J Biol Chem 271:18181-18187

121. Wu J, Rutkowski DT, Dubois M, Swathirajan J, Saunders T, Wang J, Song B, Yau GD, Kaufman RJ (2007) ATF6alpha optimizes long-term endoplasmic reticulum function to protect cells from chronic stress. Dev Cell 13:351-364. doi:10.1016/j. devcel.2007.07.005

122. Xu M, Shibayama H, Kobayashi H, Yamada K, Ishihara R, Zhao P, Takeuchi T, Yoshida K, Inagaki T, Nokura K (1992) Granulovacuolar degeneration in the hippocampal cortex of aging and demented patients-a quantitative study. Acta Neuropathol 85:1-9
123. Yamamoto K, Sato T, Matsui T, Sato M, Okada T, Yoshida H, Harada A, Mori K (2007) Transcriptional induction of mammalian ER quality control proteins is mediated by single or combined action of ATF6alpha and XBP1. Dev Cell 13:365-376. doi:10.1016/j.devcel.2007.07.018

124. Yamamoto K, Takahara K, Oyadomari S, Okada T, Sato T, Harada A, Mori K (2010) Induction of liver steatosis and lipid droplet formation in ATF6alpha-knockout mice burdened with pharmacological endoplasmic reticulum stress. Mol Biol Cell 21:2975-2986. doi:10.1091/mbc.E09-02-0133

125. Yoshida H, Haze K, Yanagi H, Yura T, Mori K (1998) Identification of the cis-acting endoplasmic reticulum stress response element responsible for transcriptional induction of mammalian glucose-regulated proteins. Involvement of basic leucine zipper transcription factors. J Biol Chem 273:33741-33749

126. Yoshida H, Matsui T, Yamamoto A, Okada T, Mori K (2001) XBP1 mRNA is induced by ATF6 and spliced by IRE1 in response to ER stress to produce a highly active transcription factor. Cell 107:881-891

127. Yu Z, Luo H, Fu W, Mattson MP (1999) The endoplasmic reticulum stress-responsive protein GRP78 protects neurons against excitotoxicity and apoptosis: suppression of oxidative stress and stabilization of calcium homeostasis. Exp Neurol 155:302-314

128. Zhang K, Wong HN, Song B, Miller CN, Scheuner D, Kaufman RJ (2005) The unfolded protein response sensor IRE1alpha is required at 2 distinct steps in B cell lymphopoiesis. J Clin Invest 115:268-281. doi:10.1172/JCI21848

129. Zhang P, McGrath B, Li S, Frank A, Zambito F, Reinert J, Gannon M, Ma K, McNaughton K, Cavener DR (2002) The PERK eukaryotic initiation factor 2 alpha kinase is required for the development of the skeletal system, postnatal growth, and the function and viability of the pancreas. Mol Cell Biol 22:3864-3874

130. Zhang YJ, Jansen-West K, Xu YF, Gendron TF, Bieniek KF, Lin WL, Sasaguri H, Caulfield T, Hubbard J, Daughrity L, Chew J, Belzil VV, Prudencio M, Stankowski JN, Castanedes-Casey M, Whitelaw E, Ash PE, DeTure M, Rademakers R, Boylan KB, Dickson DW, Petrucelli L (2014) Aggregation-prone c9FTD/ALS poly(GA) RAN-translated proteins cause neurotoxicity by inducing ER stress. Acta Neuropathol 128:505-524. doi:10.1007/s00401-014-1336-5 